\title{
Nominal anchors and the price puzzle
}

\author{
Anna Florio* \\ Politecnico di Milano
}

June 2018

This is a pre-copyedited, author-produced version of an article accepted for publication in Journal of
Macroeconomics following peer review. The version of record (A. Florio, (2018) "Nominal anchors and
the price puzzle," Journal of Macroeconomics, Volume 58, Pages 224-237) is available online at: https:
//www.sciencedirect.com/science/article/pii/S0164070418300922.

\begin{abstract}
Looking at the pre-Great Recession period, employing a VAR analysis, we compare the behavior of prices after a monetary policy shock in countries with clearly defined nominal anchors (Australia, Canada, New Zealand, Sweden, Switzerland, United Kingdom and EMU) with their behavior in countries that, at that time, did not possess any such anchor (Japan and United States). While for this last group we find evidence of a price puzzle (i.e. the positive response of prices to a negative monetary policy shock), in the first, once this anchor was set, we do not detect such a perverse dynamic. We argue that in those countries, characterised by clearly defined nominal anchors, the central bank manages to anchor inflation expectations thus ruling out the persistent increase in the price level.
\end{abstract}

\section{Introduction}

In VAR analysis, puzzling responses of economic variables (generally prices) to monetary policy shocks are usually thought to be the consequence of a misspecified central bank's policy reaction function (Sims, 1992). The proposals to solve such puzzles deal generally with the addition of (previously omitted) variables in the VAR that help overcome the inadequate description of the central bank's policy function.

This paper intends to further investigate the puzzling responses of prices to monetary policy shocks. Throughout the analysis we consider a VAR in its simplest form containing just three variables: the (log of) real GDP $(y)$, (the log of) the GDP deflator $(p)$ and the policy rate $(r)$. As many others, we think that the omitted variable, whose exclusion could determine the price puzzle, relates to inflation expectations. However, we suspect that the puzzle's severity varies with the extent of inflation expectations' anchoring by the

\footnotetext{
${ }^{*}$ Department of Management, Economics and Industrial Engineering, Politecnico di Milano, via Lambruschini 4/B, 20156 Milan, Italy. E-mail address: anna.florio@polimi.it
} 
central bank. In particular, we distinguish among three different states: anchored, contained and unmoored expectations. When inflation expectations are firmly anchored we find, in line with previous works, that there is no evidence of any price puzzle, since the central bank manages to keep the inflation process under control. However, in the presence of a central bank that manages expectations and which succeeds in containing but not firmly anchoring them, there is a price puzzle. This puzzle however disappears once a proxy for inflation expectations is included in the VAR. Finally, when expectations are unmoored they react considerably to short-run inflation surprises and the inflation process can display persistent swings away from its long-run mean. In this case, even the inclusion of further variables does not avoid the puzzling response. This happens, for example, when considering the pre-Volcker period in the United States.

The paper is organised as follows. Section 2 reexamines VAR evidence for the United States through a brief review of the literature on the price puzzle for this country. We also compare price puzzle evidence from the United States and the Euro area estimating a VAR for the pre-Great Recession period. The tentative explanation for the different results we get from these two countries is discussed in Section 3 that borrows from the literature the definitions for anchored, contained and unmoored expectations. We connect these definitions with the monetary regimes in place in various countries. The same section contains our VAR analysis devoted to checking if and how the price puzzle evidence has changed in a host of countries once they adopted clearly defined nominal anchors and what happens if inflation expectations are added in the VAR. In Section 4 we consider a DSGE model with a cost channel to find out under which conditions, despite anchored inflation expectations, this channel could deliver a price puzzle. We show that a crucial role in this sense is played by the magnitude of Calvo parameters. Section 5 concludes.

\section{The price puzzle in the United States: evidence from the literature}

According to the conventional wisdom, the price puzzle anomaly is given by the misspecification of the systematic part of policy. In particular, the VAR turns out to be misspecified if it fails to include a proxy for future inflation. According to Sims (1992) the price puzzle was the result of policy endogeneity: "policy authorities might know that inflationary pressure is about to arrive and contract to dampen the effects of these pressures. Then prices would rise after the monetary contraction (...) (p. 988)". When inflation expectations are not included in the VAR, the results of endogenous and/or anticipatory responses by the central bank emerge. Sims (1992) suggested the inclusion of a commodity price index, since this could contain information about future inflation that, correctly specifying the VAR, resolves the puzzle. Other authors detect different variables that could be of help to the central bank to forecast future inflation (such as inflation expectations from various surveys) or try to account for the large information set typically used by a central bank in taking its decisions. The factor-augmented VAR (FAVAR) approach, for example, going into this direction, should always be of help in avoiding these puzzling responses-provided they are truly due to omitted information which are essential in the 
monetary authority's decision process, (see, among the others, Bernanke et al., 2005, Boivin et al., 2009) Others correct the policy shock to take account of endogeneity/anticipatory movements (see Romer and Romer, 1994).

Here, and throughout the paper, we limit our empirical investigation to the years before the Great Recession. A simple VAR analysis, in fact, would not be suited to study monetary policy effects in a zero lower bound era when non-standard monetary tools were employed.

In this section we review the papers that deal, directly or indirectly, with the price puzzle in the United States. We collect them in different tables according to the sample period they refer to. Table 1 includes the pre-Volcker period evidence, Table 2 the (whole) sample covering both the Great Inflation and the Great Moderation, Table 3 focuses just on the years after the Great Inflation (from 1982 on). Each table is organised as follows. In the first and in the second column you find, respectively, the authors of the paper and the sample period analysed. In the third column there is the empirical technique employed (based on VAR) and the variables included; in the last column there is a $\mathrm{Y}$ or a $\mathrm{N}$ according to the presence or not of a price puzzle in the impulse response functions.

As Table 1 shows, there is always evidence of the price puzzle in the pre-Volcker sample and, what is more, it does not disappear even when a proxy for inflation expectations is included or a FAVAR approach is employed 1 As Hanson (2004) stresses, the practice to avoid the price puzzle including additional variables, such as commodity prices, does not work for all sub-sample periods, and especially in the pre-1980 period.

If the sample period is not limited to the Great Inflation but is extended to the Great Moderation years (see Table 2) there is the price puzzle but it disappears when a larger information set is used or when commodities prices or the output gap (see Giordani, 2004) or a new measure of monetary policy shock free from endogenous or anticipatory movements (see Romer and Romer, 1994) are included.

According to Hanson (2004), examining the causes and cures of the price puzzle employing a sample that contains both the pre- and post-1979 period may be inappropriate. In fact, in the period 1979-82, the Fed changed its operating procedure passing from federal funds rate targeting to non-borrowed reserves targeting. This shift could have changed both the policy reaction function and the variables the Fed reacted to in these two subsamples. For this reason, Table 3 focuses just on the post-1982 period and it shows how the price puzzle is not that evident: a monetary policy shock still produces a price puzzle that, however, is seldom statistically significant and, adding variables sometimes solves the puzzle (see Balke and Emery, 1994), some others produces output puzzles (see Boivin and Giannoni, 2006) or it limits the puzzle to a short initial period (see Barth and Ramey, 2002). Other times, however, adding commodity prices does not solve the puzzle (see Milcheva, 2013).

To sum up: the evidence of a price puzzle is more clear cut in the pre-1979 sample when adding other variables in the VAR proves, most of the time, useless. If one considers the whole extended period, there is a price puzzle that, however, can be "cured" adding variables that improve the specification. Finally, focusing

${ }^{1}$ These results refer to a VAR with a Cholesky identification. Employing this identification and adding expected inflation, Castelnuovo and Surico (2010) find a price puzzle which is not statistically significant. They find that the price puzzle unambiguously disappears when both expected inflation is added in a VAR and a sign restriction identification strategy is followed. 


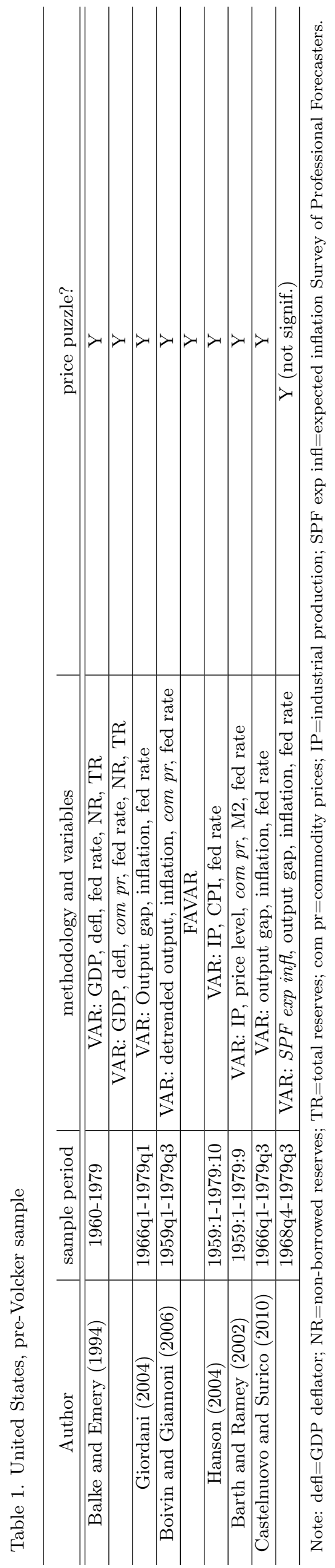




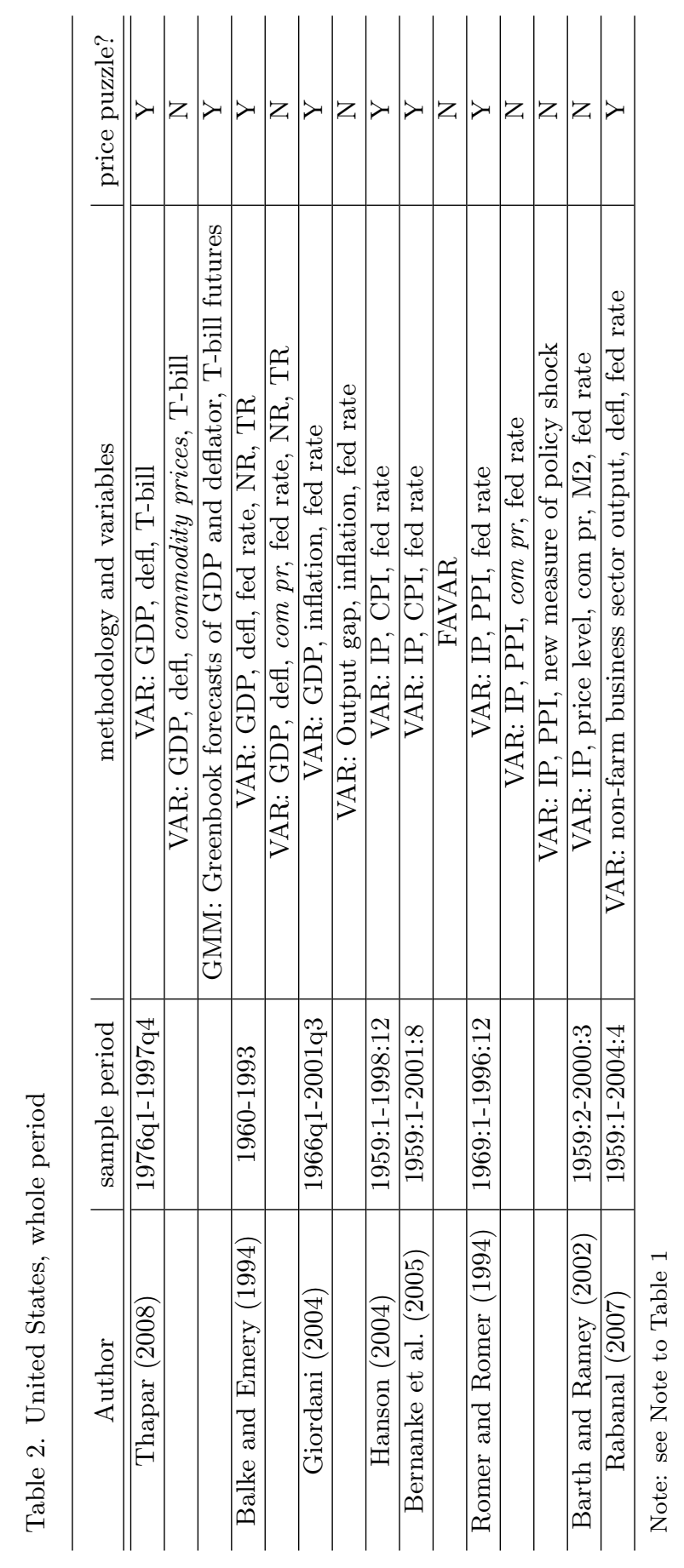




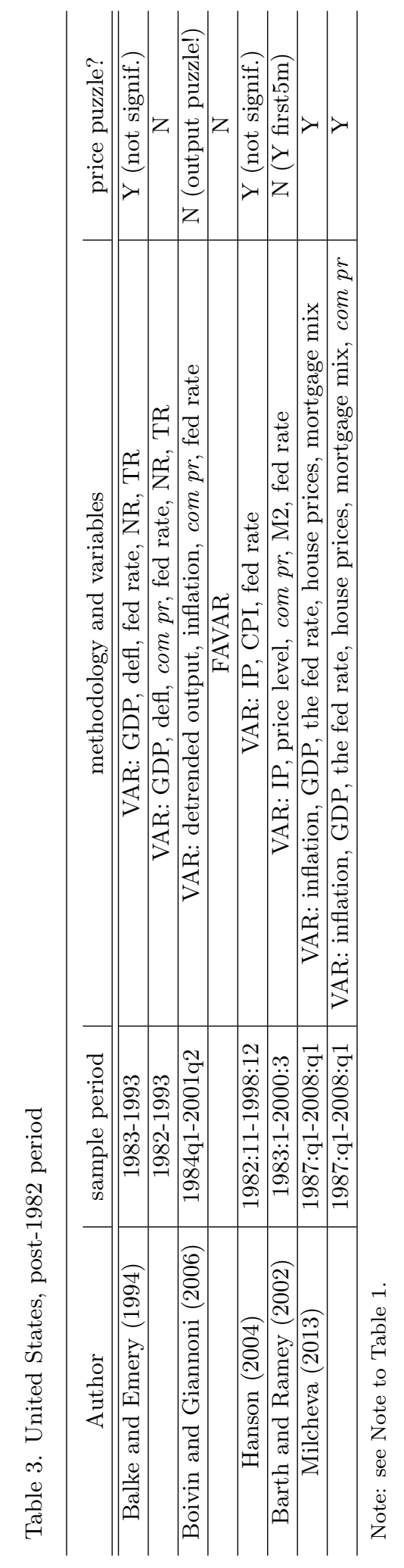


just on the post-1982 period, the results for the whole period are confirmed but both the variables reaction to the monetary shock and the price puzzle become weaker. Hence, the consequences of including any information variable vary over the sample period considered: the sample period and the monetary regime seem to be crucial elements to understand this anomalous response of prices.

\subsection{US and the Euro area: a comparison}

In this section we want to focus our attention on the years up to the start of the Great Recession. To the end of comparison, we undertake the same empirical analysis both for the United States and for the Euro area under the European Monetary Union (EMU) to disentangle any puzzling response following a monetary tightening. We construct a VAR that contains, for both countries, the following variables: the (log of) real GDP (y), (the $\log$ of) the GDP deflator $(p)$ and the policy rate $(r)$ (the federal funds rate for the Fed and the money market rate for the ECB) ${ }^{2}$ The monetary policy shock is identified employing the Cholesky decomposition where we place the nominal interest rate last in the ordering so that monetary policy reacts to contemporaneous values of the other macroeconomic variables while these are not affected by monetary policy. The sample period goes from the start of the EMU to the start date of the Great Recession for each country, as fixed by the OECD based recession indicator. Figure 1 shows the VAR impulse responses for both the United States (1999q1-2007q4) and the Euro area (1999q1-2008q2); shaded areas denote the $68 \%$ and the $90 \%$ confidence bands constructed using Monte Carlo simulations.

While there are not puzzling responses in the Euro case, the US case shows both an output and a price puzzle. Moved by this evidence, we put forth a tentative explanation for this difference that we will discuss in the next section. According to the usual interpretation, the above results should point to a misspecification problem in the Fed reaction function but not in the ECB one. That is, the simple 3-variables VAR is adequate to correctly describe the effects of monetary shocks in the Euro area but not in the United States. If the missing variable, as previous literature maintains, deals with inflation expectations then (a proxy for) this variable should be added into the VAR for the U.S. but it is not necessary for the Euro area specification (see later for this exercise). This is not to say that the ECB does not care of private sector's inflation expectations when deciding its policy. Rather, we argue that the ECB, having managed in those years to anchor inflation expectations more firmly than the Fed, has made their presence in the VAR redundant. The price variable in the VAR is itself a sufficient statistics if expectations are well anchored.

It can not be denied that both these central banks underwent in those years improvements in managing market expectations and credibility through greater transparency but, as Blinder et al. (2008) admit, talking about central bank transparency, "the Fed is more of a laggard than a leader in this regard" and again "the ECB has been more transparent than the Fed ever since it opened its doors in 1998."

The greater transparency achieved by the ECB, if compared to the Fed, allowed to anchor more firmly

\footnotetext{
${ }^{2}$ See Appendix A for a description of the dataset used throughout the paper and for methodology details.
} 

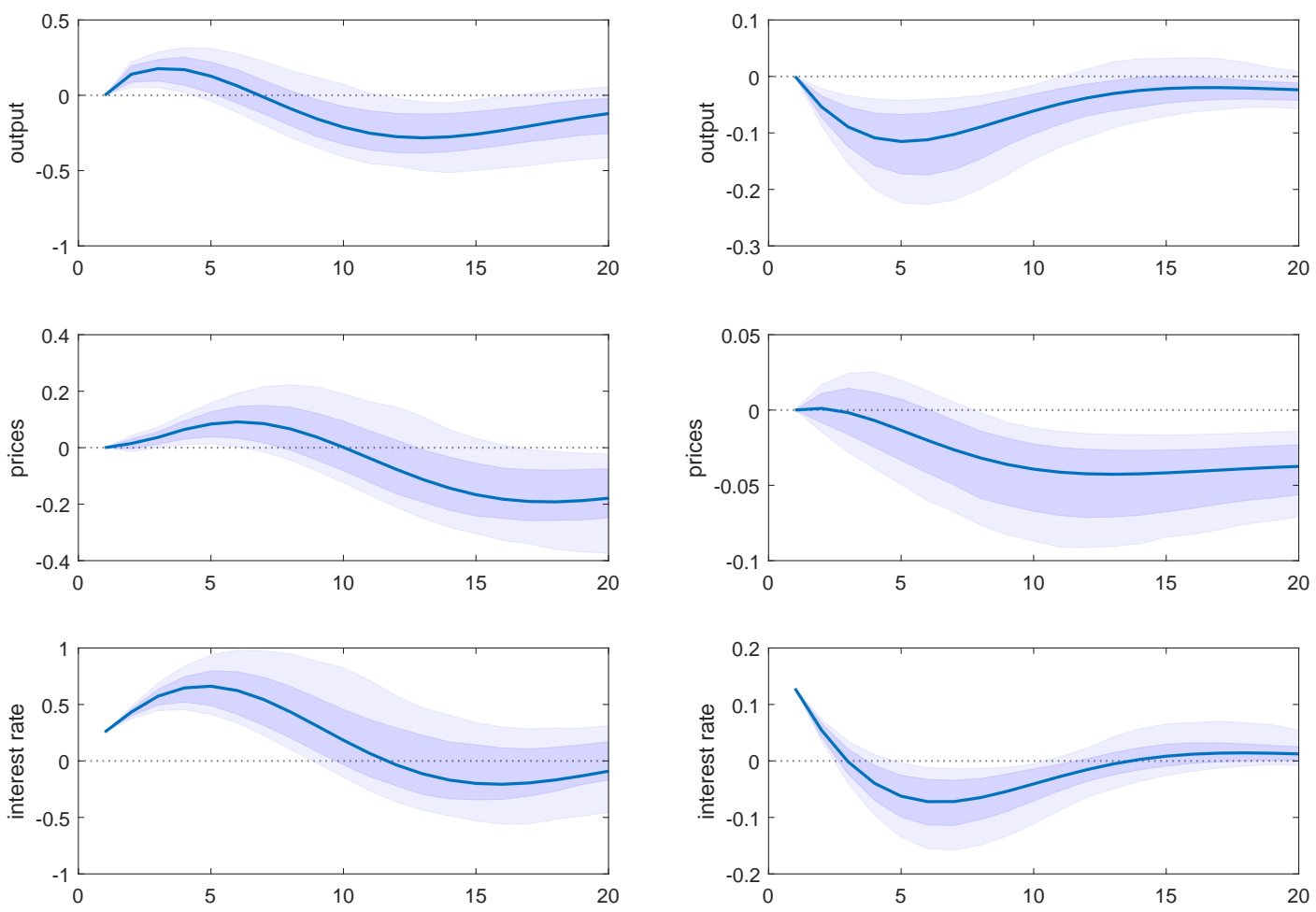

(a) USA 1999q1-2007q4

(b) Euro area 1999q1-2008q2

Figure 1: VAR impulse response functions to a contractionary monetary policy shock 
private expectations in the Euro area ${ }^{3}$ Beechey et al. (2011) support this result comparing the evolution of long-run inflation expectations in the two countries. They find a low and declining disagreement about long run inflation outcomes in the Euro area but not in the United States. Furthermore, while inflation compensation (a proxy for inflation expectations) displays systematic sensitivity to current news in the U. S., it does not in the Euro area. This evidence brings the authors to support the view of long-run inflation expectations that are not as firmly anchored in the U.S. as in the Euro area.

\section{Is there a price puzzle in countries with clearly defined nominal anchors?}

The importance of managing market expectations for the conduct of monetary policy is largely acknowledged. In FOMC minutes one can read that inflation expectations are thought to be contained rather than anchored and, sometimes, they have happened to be unanchored or unmoored. Building on Bernanke's (2007) notion of anchored expectations, Carvalho et al. (2017), claim that inflation expectations are anchored when agents' long run inflation beliefs are relatively insensitive to surprise movements in contemporaneous inflation, whereas they are poorly anchored when they display elevated sensitivity to new information.

Potter and Rosenberg (2017) provide the following definitions of anchored, contained and unmoored expectations. If the underlying inflation process driving expectations is quickly attracted to its long-run average, then expectations are anchored and the public has confidence that inflation will remain low in the long run. On the other hand, if the same process is nonlinear and characterised by a quick attraction to bounds around the long-run mean but a slow movement toward its long-run average within the bounds, expectations are contained. There are, instead, unmoored expectations when these are neither quickly attracted to the long-run mean or bounds.

Which are the consequences on the price puzzle of each of these different degrees of expectations anchoring? Furthermore, which countries and/or sample periods can be associated, in turn, with each of them?

Many authors have argued that inflation expectations in the United States were not anchored before Volcker's tenure because the Federal Reserve did not follow the so called Taylor principle. The empirical analyses they undertake for those years uncover a smaller than one coefficient for inflation in a Taylor rule: the central bank moved the nominal interest rate less than one-to-one in response to variations in inflation (see Clarida et al. 2000; Boivin and Giannoni, 2006). According to these authors, such an accommodative behavior has been responsible for inflation getting out of control in the Seventies. However, the accommodative behaviour by the central bank or, in Leeper s (1991) terminology, a passive central bank, would be consistent both with an indeterminate regime, in case of a passive fiscal authority, or with a determinate regime if fiscal policy is instead active. In the first case, indeterminacy would lead to instability and self-fulfilling inflation; in the second case,

\footnotetext{
${ }^{3}$ Some ascribe this success to the fact that the ECB provided a numerical definition of price stability that, instead, the Fed introduced later in 2012.
} 
the fiscal theory of the price level would hold and, as Leeper and Leith (2016) claim, there would be nothing puzzling in a jump of the price level after a monetary tightening $4^{4}$ Belaygorod and Dueker (2009) state that the price puzzle is not "necessarily a false finding that pertains only to mis-specified VARs" but, rather, it could be a genuine phenomenon in the presence of a passive monetary policy. In other words, if the central bank does not seek to anchor inflation expectations and hence it does not systematically respond to them, a 3-variable VAR that includes just $\left[y_{t}, p_{t}, r_{t}\right]$ could be correctly specified and the subsequent price puzzle might not be "a puzzle" but just the result of different dynamics of the economy. This seems the case for the U.S. during the Great Inflation when the inclusion of a proxy for inflation expectations or controlling for endogeneity and/or anticipatory actions does not solve the puzzle.

Although the central bank takes seriously into account private sector inflation expectations in making policy, these could happen to be just contained (rather than fully anchored). In this case inflation expectations have itself an informational value for the conduct of monetary policy. Therefore the 3-variable VAR would not be correctly specified since it would not contain inflation expectations the central bank reacts to that, in turn, affect and help explaining actual inflation. This circumstance would produce a price puzzle that fades away once inflation expectations are included in the VAR. Such seems to be the case for U.S. policy from Volcker disinflation on: according to Potter and Rosenberg (2017), in the United States there was strong evidence for inflation expectations being just contained before the Great Recession.

Announcing a numerical inflation target should be of help in anchoring long-run inflation expectations (see Blinder et al. (2008)). Gurkaynak et al. (2010) find anchored long-run inflation expectations for the United Kingdom before 1997, when the Bank of England was not independent, but not after that when an explicit and credible inflation target was set. Levin et al. (2004) claim that IT anchored inflation expectations and reduced inflation persistence. Benati (2008) confirms this view finding inflation persistence to have vanished in countries where expectations had been anchored 5 but not in those, like U.S. and Japan, that, at the time, lacked any such anchor.

When a central bank cares about price stability and takes into account inflation expectations in its decision process, a VAR including just $\left[y_{t}, p_{t}, r_{t}\right]$ would be correctly specified and would not produce any price puzzle 6 In fact, being inflation expectations anchored to a constant average- usually at the inflation target announced by the monetary authority- inflation expectations, decoupled from short run inflation dynamics, would be redundant once effective inflation has been included in the VAR as a policy decision variable. This, according to Section 2, seems to be the case for the Euro area under EMU.

\footnotetext{
${ }^{4}$ Under the fiscal theory of the price level, an increase in the nominal interest rate raises the market value of debt and households' interest receipts. The resulting wealth effects, not offset by the government that undertakes an active fiscal policy, raise the price level.

${ }^{5}$ Namely, IT countries (United Kingdom, Canada, New Zealand, Sweden), the Euro zone under EMU, Switzerland in the new Swiss monetary regime and some countries under the gold standard.

${ }^{6}$ Note that there is an additional potential source of misspecification that we do not account for in our analysis. Namely, we are implicitly assuming that monetary shocks do not affect output and prices contemporaneously even in the true DGP of the economy. Carlstrom et al. (2009) show instead that price and output puzzles may spuriously emerge in a recursive VAR if the DGP is in fact non-recursive.
} 
Do IT adopting countries, or countries that have firmly anchored inflation expectations, show puzzling responses of economic variables to a monetary shock when a simple 3-variable VAR is employed?

\subsection{An empirical investigation}

To study the link between the adoption of clearly defined nominal anchors and the price puzzle we employ the same 3-variable VAR previously used to compare the United States and the Euro area. Seven more countries are now considered: Australia, Canada, New Zealand, Sweden and United Kingdom which have adopted IT; Switzerland whose Swiss National Bank provided a quantitative definition of price stability (as ECB does) and Japan which was nor an inflation targeter neither provided a definition of price stability (as the United States) before the Great Recession 7

We study two different sample periods for each country that correspond to a pre- and post-IT regime. The regimes are identified following Benati (2008) 8 Our sample differs from Benati's in three aspects. First, we include Australia. Second, we fix the beginning of the IT regime at least three quarters after its formal introduction: this increases our confidence about its effective operation 9 Third, we extend our dataset to the years just before the Great Recession: the second regime ends at the date indicated by the OECD as the starting date of the Great Recession for each country.

Figure 2 reports the response of the non-policy variable to a one standard deviation innovation (corresponding to a positive shock) in the policy variable. The solid lines depict the estimated median responses, while the shaded bands are the $68 \%$ and the $90 \%$ percentiles constructed using Monte Carlo simulations.

Comparing the two regimes for each country, one can realise that the price puzzle always appears in the first period while it fades away in the more recent, inflation-anchored regime. This result holds for all countries except for Japan that lacked any anchor to stabilize inflation expectations and which shows a price puzzle in both periods. In the more recent period of lower inflation persistence and more anchored expectations, the price puzzle seems to dissipate in those countries where IT has been adopted or where a numerical measure of price stability is provided to the public (including the Euro area, see Figure 1) but not in those countries (as Japan or the United States) where expectations were, at that time, just contained or even unmoored 10

\footnotetext{
${ }^{7}$ While in the United States an explicit $2 \%$ inflation target was introduced in January 2012, in Japan it was introduced a year later. Note that results for Japan must be taken with a grain of salt. Since the mid 1990s, in fact, Japan is at or near the zero lower bound and hence, as for the Great Recession years, our simple VAR analysis could not be appropriated. However, we opted to keep Japan in the analysis to make this study directly comparable to Benati (2008) (that includes Japan) and to enrich the control group with another country, besides the United States, without an explicit inflation objective.

${ }^{8}$ See Benati (2008)'s Appendix 2. We report, for the reader's convenience, the dates for each regime for every country both in Appendix A and in figure 2. Due to data availability, for New Zealand we look just at the post-IT regime.

${ }^{9}$ This is true for each country except from Australia where we take as the starting date for the second sample June 1993, when IT was adopted. Our choice is motivated by the fact that, as stated by the then Governor of the Reserve Bank of Australia, Steven (1999): "An increasing focus on achieving, and then maintaining, low inflation had been a feature of the Reserve Bank's rhetoric and actions since about 1989 (...) The change was evolutionary, rather than revolutionary".

${ }^{10}$ We have checked the results' robustness estimating a four-variable VAR introducing the nominal exchange rate for small open economies in the sample, namely: Australia, Canada, New Zealand, Sweden and Switzerland. While in the pre-IT sample the price puzzle persists, in the post-IT sample the change in the price level is not significantly different from zero, confirming the absence of a price puzzle for these countries in their IT regime. See Appendix B.
} 

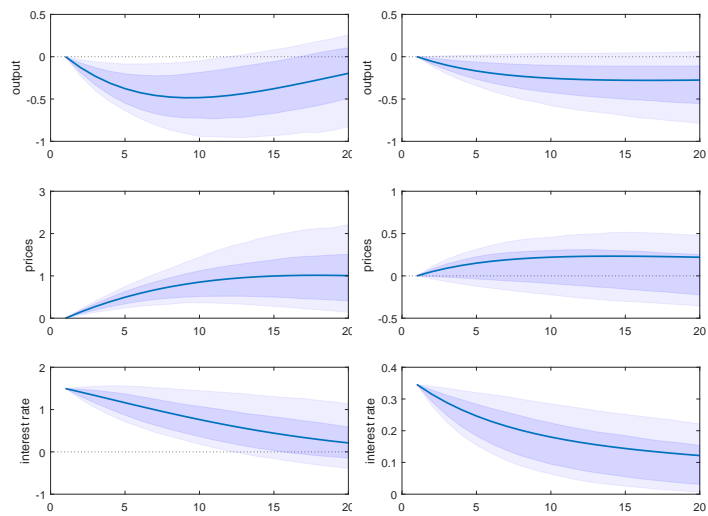

(a) Austr. 1976q3-1993q1

(b) Austr. 1993q2-2007q4
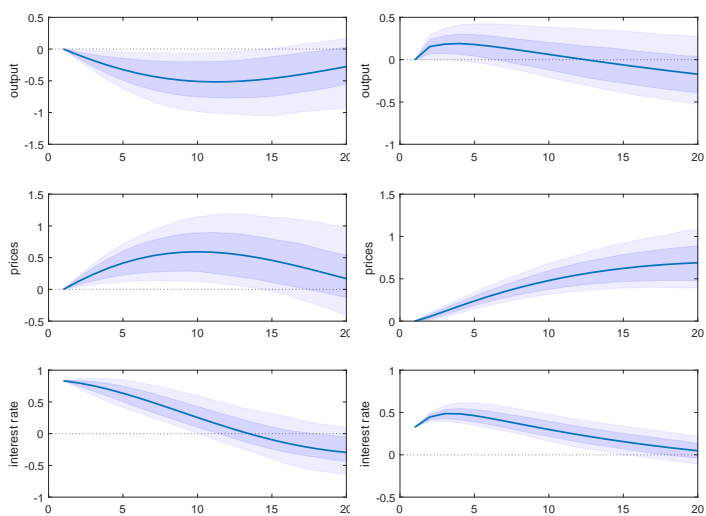

(e) Japan 1971q3-1982q4

(f) Japan 1983q1-2007q4
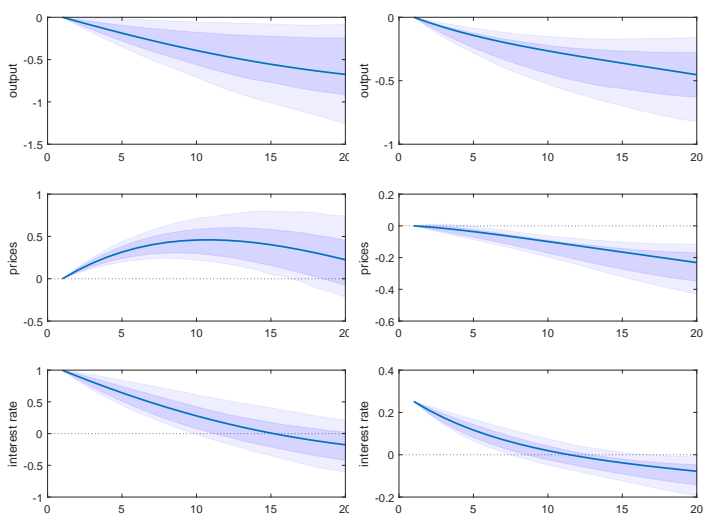

(j) Switz. 1975q4-1999q4

(k) Switz. 2000q4-2008q1
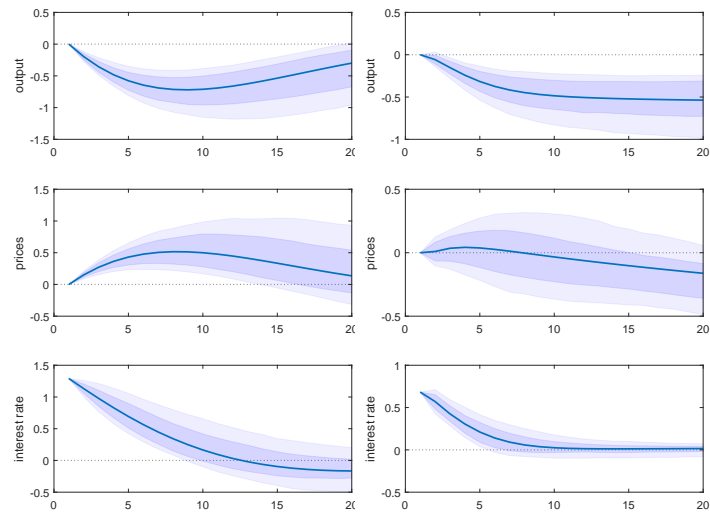

(c) Canada 1971q3-1990q4 (d) Canada 1991q4-2007q2
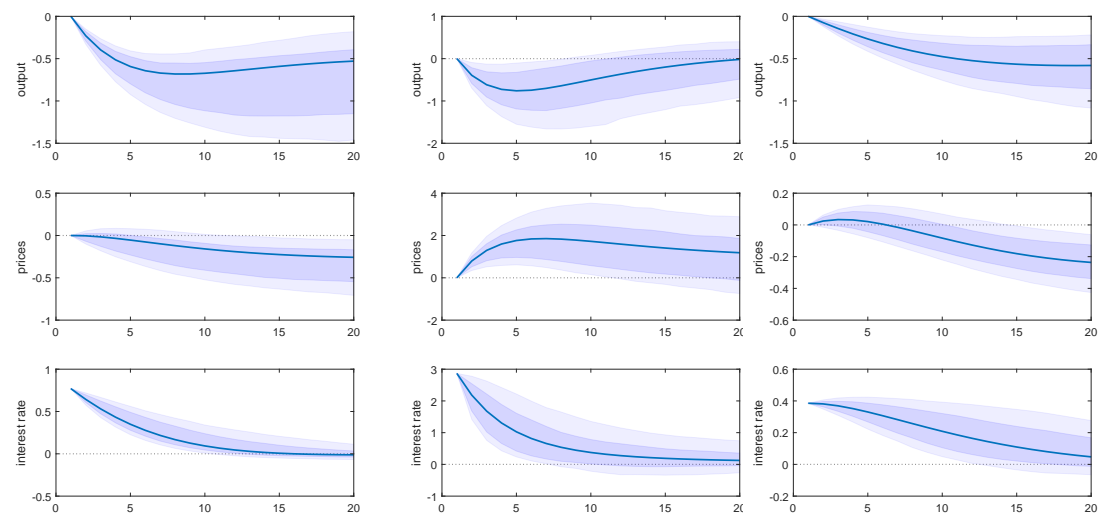

(g) NewZea 1990q4-2007q2

(h) Sweden 1971q3-1992q3 (i) Sweden 1995q1-2007q3
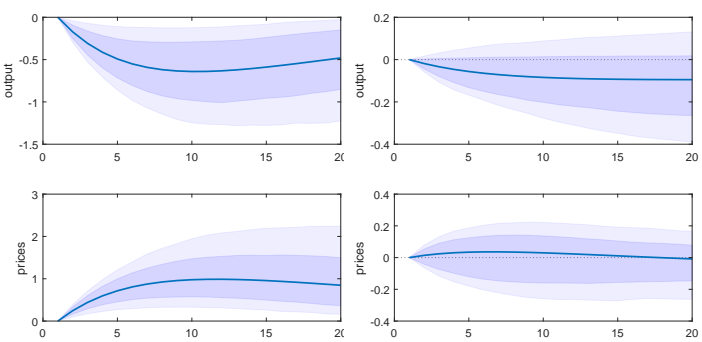

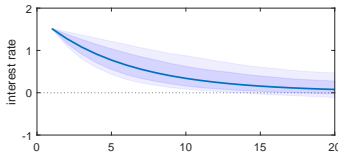

(1) UK 1972q3-1992q3

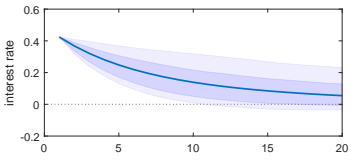

(m) UK 1993q3-2007q4

Figure 2: VAR impulse response functions to a contractionary monetary policy shock 


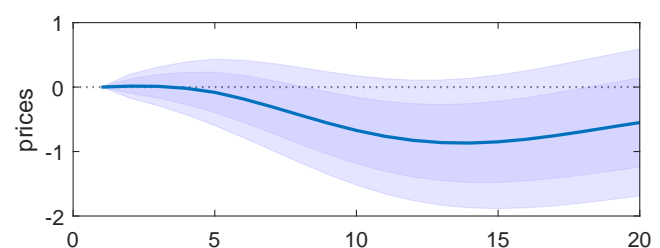

(a) USA 1999q1-2007q4

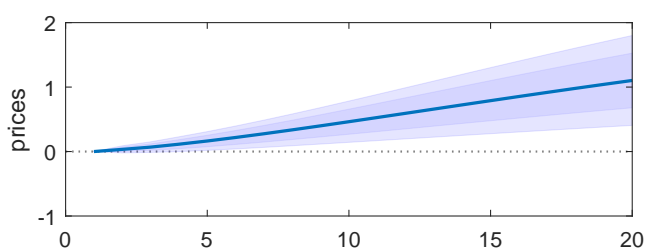

(b) Japan 1989q4-2007q4

Figure 3: Response of prices to a contractionary monetary policy shock in a VAR that includes inflation expectations

\subsubsection{Including inflation expectations}

As a final step of our analysis, we add a measure of inflation expectations in the VAR to check if and how the price puzzle results change ${ }^{11}$ When available, we used the expectations on consumer prices in the next 12 months contained in the Consumer Opinion Surveys of the OECD ${ }^{12}$ Since inflation expectations data in most cases start in the mid of the 1990s, we concentrate just on the second sample. We plot the cumulative response of inflation to make it comparable to the previous graphs that show the response of the price level. Figure 3 shows the results for countries without an explicit inflation target. For these countries the introduction of inflation expectations could help disentangle between the unmoored or contained explanations for the price puzzle ${ }^{13}$

Once we introduce inflation expectations, the price puzzle vanishes in the U.S., supporting the view that it was due to inflation expectations that were just contained. As for Japan, if we add our measure of inflation expectations (that starts in 1989q4), we get for the period 1989q4-2007q4 that the price puzzle persists, supporting the view of unmoored expectations in this country. Finally, as expected, when inflation expectations are included in the VAR for countries with clearly defined nominal anchors, the absence of a price puzzle is confirmed: the response of prices to monetary policy shocks becomes not significantly different from zero, a result, in any case, consistent with the non-inertial inflation that characterizes inflation targeting regimes ${ }^{14}$

\footnotetext{
${ }^{11}$ As data on expectations are in differences (inflation) rather than levels (prices), we had to change the VAR specification. A VAR including one-year inflation expectations, effective inflation, the output gap and the interest rate, in this order, has been estimated. Following Giordani (2004) we employ the output gap, in place of the (log of) real GDP, because its omission could spuriously produce a price puzzle.

${ }^{12}$ Whenever these were not available (New Zealand, Japan and Canada), we employed alternative sources (see Appendix A).

${ }^{13}$ Changing the specification (from the price level to inflation and from log real GDP to the output gap), as pointed out by a referee, could cause the price puzzle to disappear even if inflation expectations are not explicitly included. This is explained by the fact that the output gap is itself a powerful predictor of inflation (see Stock and Watson. 1999) so that an explicit measure of inflation expectation could be redundant to avoid the price puzzle. In line with our findings, we get that in case of contained inflation expectations (as for the United States), the presence of the output gap turns out to be sufficient to avoid the price puzzle. However, this is not true when inflation expectations are unmoored (as in the Japan case). For countries with clearly defined nominal anchors, the response of prices to the monetary policy shock remains not significantly different from zero, even once we adopt this alternative VAR specification. Results are available from the author upon request.

${ }^{14}$ For the sake of brevity we do not report these figures that are available from the author upon request.
} 


\section{Anchored expectations and the cost channel: what evidence for the price puzzle?}

Until now we have disregarded an alternative theoretical explanation for the price puzzle: the presence of a cost channel of monetary policy. If firms must pay wage-bills to workers before receiving their revenues from sales, they depend on credit to finance these payments. In this case, the interest rate charged from the financial intermediary on the borrowed funds will enter into the firm's real marginal costs. After a monetary policy tightening, the interest rate increase by the central bank makes borrowing more expensive and, as a result, inflation soars. If this "supply side" effect happens to dominate the "demand side" traditional liquidity effect, the price puzzle emerges. If, on the other hand, real wages are flexible, they can, by going down, offset the impact of the higher interest rate on the marginal cost making the price puzzle vanish.

Barth and Ramey (2002), looking for evidence of a cost channel employing a VAR analysis, compare the pre-Volcker period to the Volcker-Greenspan one. They find that the very strong cost-channel effects of the first sample become much weaker in the most recent one 15 They conclude that, with this channel at work, the rise in prices following a monetary contraction obtained in the pre-Volcker period can not be considered a puzzle.

In the previous pages we found that the price puzzle disappears when inflation expectations are anchored. We now want to check if, in case of anchored inflation expectations, the price puzzle can show up when a cost channel is operating. To this end, we employ the DSGE model by Christiano et al. (2005) that features anchored inflation expectations and includes a working capital assumption ${ }^{16}$ There the presence of a cost channel is a necessary (though not sufficient) condition to have a price puzzle and, actually, the model simulations deliver always such a perverse dynamic when the authors' (key) benchmark parameters are used.

According to Benati (2008), the anchoring of expectations comes with a reduction in inflation persistence and in the practice of indexation: the indexation parameter turns out to be very low or zero under stable regimes with clearly defined nominal anchors, pointing to a purely forward looking inflationary process. Even Hofmann et al. (2012) confirm Benati's view that indexation is not structural in the sense of Lucas (1976). However, even Calvo parameters should not be considered structural. Ball et al. (1988) recognised a direct relationship between average inflation and price flexibility. With staggered contracts, they maintain, a higher rate of inflation makes prices go out of line more rapidly and this increases the frequency of price changes. Therefore prices should be less flexible when inflation is low and stable.

When a cost channel is at work, how does the price puzzle evidence change as Calvo parameters change? We replace the traditional (hybrid) Phillips curve by an entirely forward looking one, like that found by Benati (2008) during regimes with clearly defined nominal anchors. Figure 4 shows the contour lines corresponding to the impact response of prices to a contractionary monetary policy shock, for different values of the Calvo

\footnotetext{
${ }^{15}$ Among the possible explanations they propose: the existence, in the later period, of alternative sources of funds and the absence of monetary tightening coupled with restrictive credit actions.

${ }^{16}$ Since this model is well known in the literature, we report in Appendix $\mathrm{C}$ only the log-linearized equations of the model.
} 


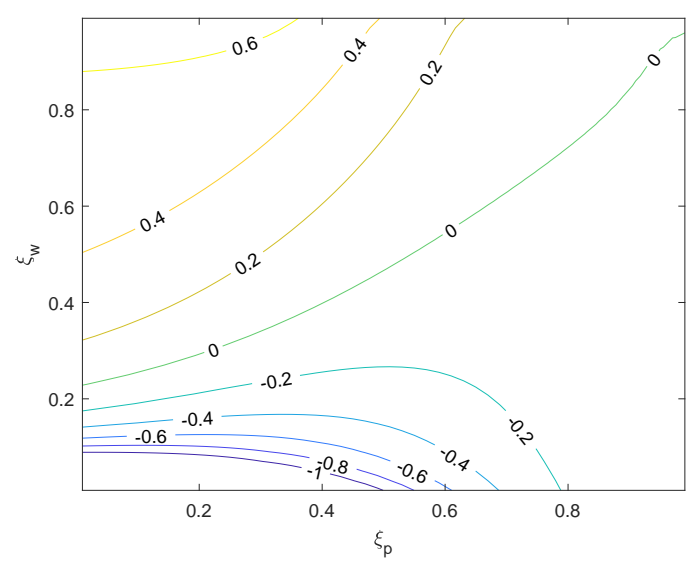

Figure 4: Contour lines for the impact price change to a contractionary monetary policy shock

parameters of price and wage rigidity ( $\xi_{p}$ and $\xi_{w}$, respectively).

As the figure shows, the presence of a price puzzle is contingent to the degree of rigidity in prices and wages. In particular, when price rigidity is high and/or wage rigidity is low, the demand effect exceeds the supply effect and there is no price puzzle. The responsiveness of inflation to the marginal cost in the Phillips curve, in fact, depends on a coefficient that is negatively related to price stickiness: with high price rigidity, inflation is less responsive to the real marginal cost (see appendix C). Furthermore, flexible wages prevent the smooth response needed to make supply effects prevail. On the other hand, the more flexible prices become, the higher is the degree of wage flexibility required to avoid a price puzzle. To sum up, if the anchoring of inflation expectations, decreasing inflation persistence, induces a minor need to change prices, the price puzzle can be avoided even when a cost channel is at work. It could suffice an high amount of price rigidity, greater than wage rigidity, to get the result. If, on the other hand, prices are flexible and wages are rigid a large price puzzle emerges even if expectations are anchored ${ }^{17}$

This result is consistent with previous works on the argument but, at the same time, adds up to new evidence. While we study how the responsiveness of price changes for different values of both price and wage Calvo parameters, Rabanal (2007) shuts down each of them one at a time (with the other fixed at its benchmark value). He points out that, among the features necessary to make the demand effects prevail and inflation fall after a monetary contraction, beside a low degree of wage indexation, one needs a high degree of price stickiness, together with a low degree of wage stickiness. He finds these features to prevail once he estimates the DSGE model with U.S. data 18 This finding is consistent with the evidence that, after the Great Moderation, price rigidity seems higher not only in absolute terms but even relative to wage rigidity. Fernandez-Villaverde and Rubio-Ramirez (2007) find that, starting from the nineties, as inflation goes down, wage rigidity goes down too

\footnotetext{
${ }^{17}$ Considering an hybrid Phillips curve with indexation to past inflation affects the amplitude and the persistence of the response of prices but not its sign. The figure we get in that case, though very similar, shows a smaller area of the parameters that does not deliver any price puzzle. Results are available from the author.

18 Christiano et al. (2005) find that when their model is estimated under an entirely forward looking Phillips curve it gives a higher price stickiness (0.72 in place of 0.6$)$ and a lower wage stickiness (0.49 instead of 0.64$)$ : a parameter combination that, according to our results, would not deliver any price puzzle.
} 
and that, in the United States, price rigidity is always larger than wage rigidity: a result common even to other countries 19

Therefore, when price rigidity is much larger than wage rigidity, as it happens in the U.S., price puzzle evidence cannot be explained by the cost channel but, rather, it calls for alternative explanations. We impute the presence of the price puzzle found in the U.S. data to a misspecified VAR due to contained expectations.

\section{Conclusions}

This paper discusses the puzzling response of prices after a monetary tightening delivered by a VAR. Since the bulk of empirical studies on the argument focuses on U.S. evidence, we have first tried to disentangle empirical regularities surveying the papers that deal, directly or indirectly, with the price puzzle in this country. We find that the price puzzle result is affected by the state of inflation expectations as well as by the monetary regime in place.

During the Great Inflation, with the central bank loosing control over prices, indexation and second round effects prevail, making the price puzzle an empirical regularity. This result is due, we maintain, to the unmoored state of market expectations. During the Great Moderation, instead, empirical evidence from the literature shows that the price puzzle disappears if inflation expectations are included in the VAR. As a result, inflation expectations can be considered contained since they provide additional information to the central bank that is not included in the actual inflation rate. Our empirical analysis for the more recent period, up to the pre-Great Recession years, confirms this result for the United States. In addition, we check if countries that adopted IT, or with well-anchored inflation expectations, show a price puzzle. In the analysed countries, without including any proxy for inflation expectations, we do not find such a perverse dynamic. Introducing inflation expectations does not change qualitatively this result. We conclude that countries characterised by clearly defined nominal anchors, having anchored inflation expectations, have managed to rule out the persistent increase in the price level.

Finally, we explore another well-known explanation for the price puzzle result: the presence of a cost channel. Employing a standard DSGE model with anchored expectations and a cost channel, we find that the presence of a price puzzle is contingent to the degree of rigidity of prices and wages. The price puzzle is absent when price rigidity is high and larger than wage rigidity. The anchoring of expectations, making inflation low and less persistent (Benati, 2008), contributes to increasing price rigidity (Ball et al., 1988) and this can make the price puzzle disappear even when a cost channel is at work.

\footnotetext{
${ }^{19}$ See, for example, the results for the United Kingdom for the post 1979 period in DiCecio and Nelson (2007) and those for the Euro area where Smets and Wouters (2003) and Warne et al. (2008), after the eighties, find a larger price (0.9) than wage rigidity $(0.7)$.
} 


\section{Appendix A}

We construct a VAR that contains: the (log of) real GDP $(y)$, (the $\log$ of) the GDP deflator $(p)$ and the policy rate $(r)$. Whenever the policy rate was not available, we replaced it with a money market interest rate. Results are robust to different choices of short-term rates. The monetary policy shock is identified employing the Cholesky decomposition where we place the nominal interest rate last in the ordering so that monetary policy reacts to contemporaneous values of the other macroeconomic variables while these are not affected by monetary policy. The starting date of the Great recession for each country is the date fixed by the OECD based recession indicator. If not otherwise stated, one lag has been employed.

\section{Euro area}

Sample period: from the start of the EMU to the start date of the Great Recession, 1999Q1 to 2008Q2.

Data: Real GDP is reference chained, seasonally adjusted, domestic currency; source: IMF-IFS. GDP deflator is seasonally adjusted; source: IMF-IFS. The interest rate is the money market interest rate, Percent per annum; source: IMF-IFS. The output gap is constructed using the Hodrick-Prescott (HP) filter. Inflation expectations are from Consumer Opinion Surveys, Consumer Prices: Future Tendency of Inflation, Net Percent, Seasonally Adjusted (CSINFT02EZM460S), starting date: 1985q1, source: OECD.

\section{United States}

Sample period: from the start of the EMU to the start date of the Great Recession, 1999Q1-2007Q4.

Data: Real GDP is Billions of Chained 2009 Dollars, Quarterly, Seasonally Adjusted Annual Rate [GDPC1]; source: U.S. Bureau of Economic Analysis. GDP Deflator is Implicit Price Deflator, Index 2009=100, Quarterly, Seasonally Adjusted [GDPDEF]; source: U.S. Bureau of Economic Analysis. The interest rate is the Federal Funds Effective Rate (\% P.A.), Selected Interest Rates (H.15) [FFO]; souce: U.S. Board of Governors of the Federal Reserve System. The commodity price index is the Producer Price Index (PPI) - Commodity Series [WPU03THRU15]: Industrial Commodities, (Index 1982=100, NSA); source: U.S. Bureau of Labor Statistics (BLS). The output gap is constructed as the difference between the (log of the) real GDP and the (log of the) potential output by the CBO. Inflation expectations are from Consumer Opinion Surveys, Consumer Prices: Future Tendency of Inflation, (CSINFT02USM460S), starting date: 1978q1, source:OECD.

Lags: two.

\section{Australia}

Sample period: the first sample goes from 1976q3 (when the availability of the money market rate begins) to the quarter before the introduction of the inflation target: 1976q3-1993q1. the second sample goes from IT (which was introduced on June 1993) to the start of the Great Recession, 1993q2-2007q4.

Data: Real GDP is Total GDP, National Currency, Quarterly, Seasonally Adjusted [AUOCM001G], source: OECD. Nominal GDP is Current Price GDP, Quarterly, Seasonally Adjusted [AUONA001B], source: OECD. GDP Deflator is obtained by dividing the nomial GDP by the real GDP. The interest rate is the Money Market 
rate, Percent per annum, source: IMF-IFS. The exchange rate is the reciprocal of U.S. dollars to one Australian dollar (DEXUSAL), source: Board of Governors of the Federal Reserve System. The output gap is constructed using the HP filter. Inflation expectations are from Consumer Opinion Surveys, Consumer Prices: Future Tendency of Inflation (CSINFT02AUM460S), starting date: 1995q1, source: OECD.

\section{Canada}

Sample period: the first sample goes from the collapse of Bretton Woods to the introduction of IT (February 26, 1991), 1971q3-1990q4. The second from the IT regime to the start of the Great Recession, 1991q4-2007q2. Data: Real GDP [CNOEXO03D], source: OECD, Quarterly national account. Nominal GDP [CNOEXA03B], source: OECD. GDP Deflator is obtained by dividing the nominal GDP by the real GDP. The interest rate is the immediate Rate, less than 24 hours: Central Bank Rates for Canada, Percent, Quarterly, Not Seasonally Adjusted [IRSTCB01CAQ156N], source: Board of Governors of the Federal Reserve System. When the money market rate by the IMF-IFS is used results are unchanged. The exchange rate is Canadian dollars to one U.S. dollar (DEXCAUS), source: Board of Governors of the Federal Reserve System. The output gap is constructed using the HP filter. Inflation expectations are 1-year forecasts, starting date 1989q4, source: Consensus Economics.

Lags: two in the second sample.

\section{Japan}

Sample period: the first sample is the post- Bretton Woods period, 1971q3-1982q4. The second ranges from the post-Great Inflation episode (set to January 1983) to the start of the Great Recession, 1983q1-2007q4.

Data: Real GDP [JPOEXO03D], source: OECD, Quarterly national account. Nominal GDP [JPOEXA03B], source: OECD. GDP Deflator is obtained by dividing the nominal GDP by the real GDP. The interest rate is the money market rate [JPQ60B..], source: IMF-IFS. The output gap is constructed using the HP filter. Inflation expectations are 1-year forecasts, starting date 1989q4, source: Consensus Economics.

Lags: two in the second sample.

\section{New Zealand}

Sample period: since we lack data for New Zealand pre-1990, we look just at one sample from IT (which was introduced on February 1, 1990) to the start of the Great Recession, 1990q4-2007q2.

Data: Real GDP is Total GDP, National Currency, Quarterly, Seasonally Adjusted [NAEXKP01NZQ189S], source: OECD. Nominal GDP is Current Price GDP, Billions of New Zealand Dollars, Quarterly, Seasonally Adjusted [NZLGDPNQDSMEI], source: OECD. GDP Deflator is obtained by dividing the nomial GDP by the real GDP. The interest rate is the Money Market rate, Percent per annum, source: IMF-IFS. The exchange rate is the reciprocal of U.S. dollars to one New Zealand dollar (DEXUSNZ), source: Board of Governors of the Federal Reserve System. The output gap is constructed using the HP filter. Inflation expectations are B3 Expected inflation 1-year (mean), Household expectations of inflation, starting date 1995Q1, source: Reserve 
Bank of New Zealand.

\section{Sweden}

Sample period: the first sample goes from the collapse of Bretton Woods to the quarter before the collapse of the fixed exchange rate regime that happened in 1992q4, 1971q3-1992q3. While the IT regime was announced on January 1993, it was put into practice in 1995. We take this date as the beginning of the second regime that ends at the start of the Great Recession, 1995q1-2007q3.

Data: Real GDP [SWOEXO03D], source: OECD, Quarterly national account. Nominal GDP [SWOEXA03B], source: OECD. GDP Deflator is obtained by dividing the nominal GDP by the real GDP. The interest rate is the money market rate [SWQ60B..], source: IMF-IFS. The exchange rate is Swedish kronor to one U.S. dollar (DEXSDUS), source: Board of Governors of the Federal Reserve System. The output gap is constructed using the HP filter. Inflation expectations are from Consumer Opinion Surveys, Consumer Prices: Future Tendency of Inflation (CSINFT02SEM460S), starting date 1995q4, source OECD.

\section{Switzerland}

Sample period: the first goes from the collapse of Bretton Woods to the introduction of the new "monetary policy concept" (on January 1, 2000), 1975q4-1999q4. The second goes from the post-2000 regime to the start of the Great Recession, 2000q4-2008q1.

Data: Real GDP [SWOEXO03D], source: OECD, Quarterly national account. Nominal GDP [SWOEXA03B], source: OECD. GDP Deflator is obtained by dividing the nominal GDP by the real GDP. The interest rate is the money market rate [SWQ60B..], source: IMF-IFS.The exchange rate is Swiss francs to one U.S. dollar (DEXSZUS), source: Board of Governors of the Federal Reserve System. The output gap is constructed using the HP filter. Inflation expectations are from Consumer Opinion Surveys, Consumer Prices: Future Tendency of Inflation (CSINFT02CHQ460S), starting date 1972q4, source: OECD.

\section{United Kingdom}

First sample period: from June 23, 1972 to the introduction of inflation targeting (on October 8, 1992), 1972q31992q3.

Data: Real GDP is at Market Prices in the United Kingdom, Millions of Chained 2013 British Pounds, Quarterly, Seasonally Adjusted [RGDPMPUKQ]; source: U.S. Bureau of Economic Analysis. Nominal GDP is at Market Prices in the United Kingdom, Millions of British Pounds, Quarterly, Seasonally Adjusted [NGDPMPUKQ]; source: Bank of England. GDP Deflator is obtained by dividing the nominal GDP by the real GDP. The interest rate is the Money Market Interest rate, Percent per annum; source: IMF-IFS.

Second sample period: from the IT regime to the start of the Great recession, 1993q3-2007q4.

Data: Real GDP is Millions of Chained 2010 National Currency, Quarterly, Seasonally Adjusted CLVMNACSCAB1GQUK; source: Eurostat. GDP Deflator is Implicit Price Deflator in United Kingdom, Index 2010=100, Quarterly, Seasonally Adjusted [GBRGDPDEFQISMEI]; source: OCSE. The interest rate: see before. The 
output gap is constructed using the HP filter. Inflation expectations are from Consumer Opinion Surveys, Consumer Prices: Future Tendency of Inflation (CSINFT02GBM460S), starting date 1985q1, source: OECD. 


\section{Appendix B}

If we include the nominal exchange rate in the VAR for small open economies (i.e., Canada, Sweden, Switzerland and Australia), while in the pre-IT regime the price puzzle persists, in the post-IT one the change in the price level is not significantly different from zero ${ }^{20}$

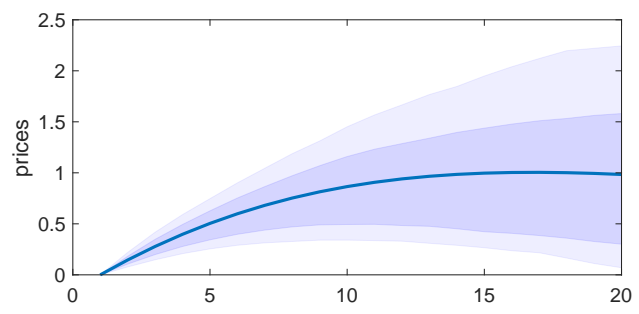

(a) Austr. 1976q3-1993q1

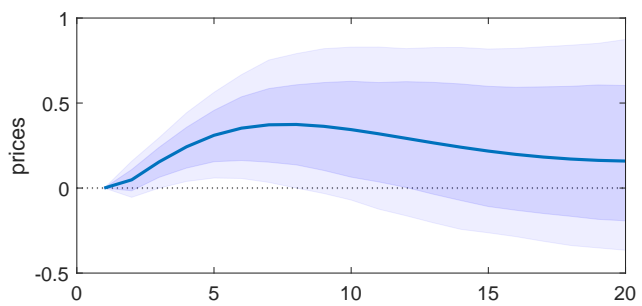

(c) Canada 1971q3-1990q4

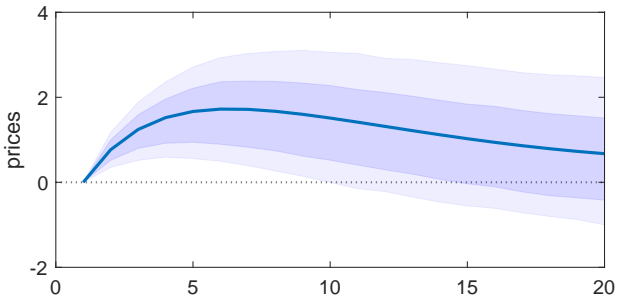

(e) Sweden 1971q3-1992q3

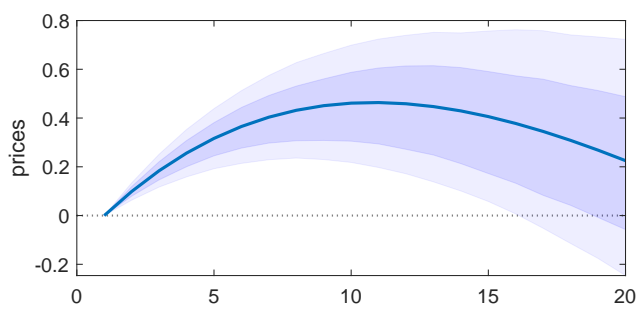

(g) Switz. 1975q4-1999q4

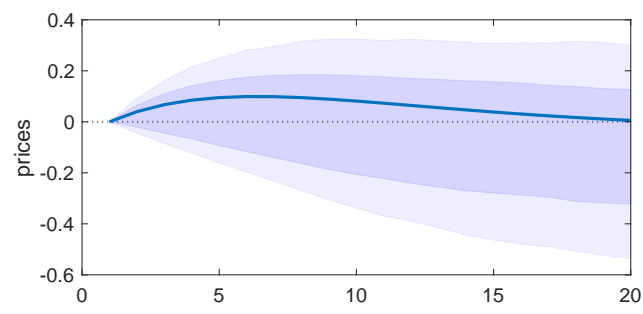

(b) Austr. 1993q2-2007q4

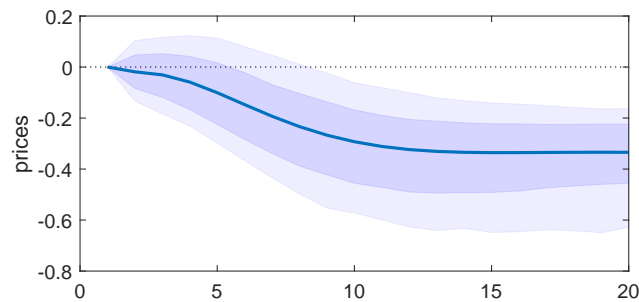

(d) Canada 1991q4-2007q2

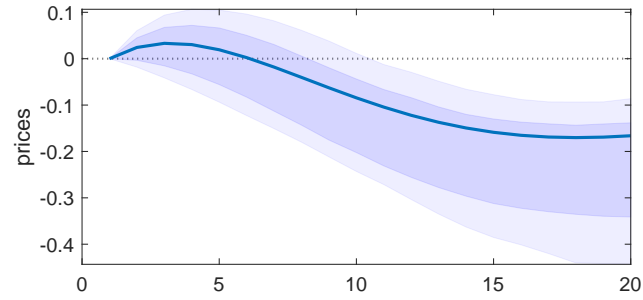

(f) Sweden 1995q1-2007q3

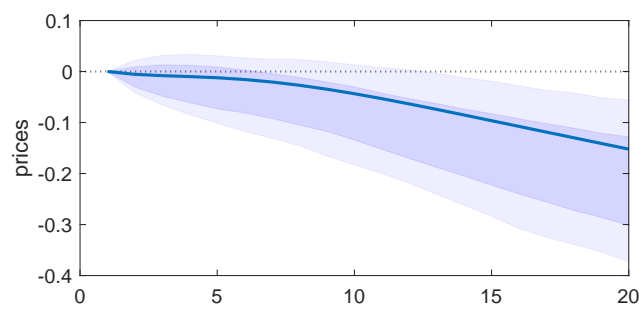

(h) Switz. 2000q4-2008q1

Figure 5: Impulse response of the price level to a contractionary monetary policy shock when the VAR includes the nominal exchange rate

\footnotetext{
${ }^{20}$ We get the same result for New Zealand whose figure, however, is not reported since we lack data for its pre-IT regime.
} 


\section{Appendix $\mathrm{C}$}

This appendix describes the linearised system in Christiano et al. (2005). For convenience, model parameters and variables are summarized in Table 4 .

The model incorporates both nominal frictions (sticky prices and wages) and dynamics in preferences and production (habit formation in consumption, investment adjustment costs, and variable capital utilization). Prices and wages are fixed according to Calvo (1983); firms not allowed to reoptimize their pricing and wage decision index them to the previous period's inflation. As in the model by Calvo (1983), a firm can only reoptimize the nominal price with probability $\left(1-\xi_{p}\right)$. In this case, the firm reoptimizes before the monetary policy shock realization. If it can not reoptimize, and this happens with probability $\xi_{p}$, prices are just indexed to lagged inflation: $P_{j t}=\pi_{t-1} P_{j, t-1}$ with $\pi_{t}=P_{t} / P_{t-1}$. This specification is called "dynamic" to distinguish it from the "static" price-updating scheme that, instead, indexes prices not to past inflation but to the steady state gross rate of inflation $(\bar{\pi}): P_{j, t}=\bar{\pi} P_{j, t-1}$. As a consequence, in this model, $\xi_{p}$ signals the degree of price stickiness.

The implied inflation dynamics are given by the following Phillips curve:

$$
\widehat{\pi}_{t}=\frac{1}{1+\beta} \widehat{\pi}_{t-1}+\frac{\beta}{1+\beta} E_{t-1} \widehat{\pi}_{t+1}+\frac{\left(1-\beta \xi_{p}\right)\left(1-\xi_{p}\right)}{(1+\beta) \xi_{p}} E_{t-1} \widehat{s}_{t}
$$

with the real marginal cost $\widehat{s}_{t}$ given by:

$$
\widehat{s}_{t}=\alpha \widehat{r}_{t}^{k}+(1-\alpha) \widehat{w}_{t}
$$

where hats on variables indicate the log-deviations from steady-state values. This is an hybrid new Keynesian Phillips curve since it contains, beside a forward looking term for inflation, even a backward looking one due to the presence of dynamic indexation that introduce, in a rather ad hoc way, the greater persistence in inflation usually found in the data. Whenever the other (static) form of indexation were used, the above equation would reduce to the following:

$$
\hat{\pi}_{t}=\beta E_{t-1} \hat{\pi}_{t+1} \frac{\left(1-\beta \xi_{p}\right)\left(1-\xi_{p}\right)}{\xi_{p}} E_{t-1} \hat{s}_{t}
$$

where current inflation depends just on future inflation.

The nominal wage equation is given by:

$$
\begin{aligned}
0= & \widehat{w}_{t-1}-\frac{b_{w}\left(1+\beta \xi_{w}^{2}\right)-\lambda_{w}}{b_{w} \xi_{w}} E_{t-1} \widehat{w}_{t}+\beta E_{t-1} \widehat{w}_{t+1}+E_{t-1}\left[\beta\left(\widehat{\pi}_{t+1}-\widehat{\pi}_{t}\right)-\left(\widehat{\pi}_{t}-\widehat{\pi}_{t-1}\right)\right] \\
& +\frac{1-\lambda_{w}}{b_{w} \xi_{w}} E_{t-1} \widehat{\psi}_{t}-\frac{1-\lambda_{w}}{b_{w} \xi_{w}} E_{t-1} \widehat{L}_{t}
\end{aligned}
$$

Firms' optimality conditions imply that their total payments for capital services equal their total cost of hiring labor each period:

$$
\widehat{r}_{t+1}^{k}=\widehat{w}_{t+1}+\widehat{R}_{t+1}+\widehat{L}_{t+1}-\widehat{K}_{t+1}
$$


The assumption underlying this condition is that firms finance their wage bill with funds borrowed one period earlier. Real unit labor costs are therefore (in log terms) equal to the sum of the real wage and the short-term nominal interest rate.

The typical household's intertemporal Euler equation for consumption and first-order condition for capital purchases are, respectively,

$$
\begin{gathered}
E_{t}\left\{\widehat{\psi}_{t+1}+\widehat{R}_{t+1}-\widehat{\pi}_{t+1}-\widehat{\psi}_{t}\right\}=0 \\
0= \\
E_{t-1}\left\{-\widehat{P}_{k^{\prime}, t}-\widehat{\psi}_{t}+\widehat{\psi}_{t+1}+(1-\beta(1-\delta))\left[\widehat{\bar{w}}_{t+1}-\widehat{\pi}_{t+1}+\widehat{R}_{t+1}+\widehat{L}_{t+1}-\widehat{K}_{t+1}\right]+\beta(1-\delta) \widehat{P}_{k^{\prime}, t+1}\right\}
\end{gathered}
$$

Because of habit formation in preferences, the household marginal utility of consumption depends on the current, prior, and expected future levels of consumption:

$$
\begin{gathered}
\widehat{H}_{t}-\chi \widehat{H}_{t-1}-(1-\chi) \widehat{c}_{t-1}=0 \\
E_{t-1}\left\{-\beta \chi \widehat{\psi}_{c, t+1}+\sigma_{c}\left[\widehat{c}_{t}-\frac{b}{1-\chi} \widehat{H}_{t}\right]-(b+\chi) \beta \sigma_{c}\left[\widehat{c}_{t+1}-\frac{b}{1-\chi} \widehat{H}_{t+1}\right]+\widehat{\psi}_{c, t}\right\}=0
\end{gathered}
$$

The economy's technology allows additional productive services to be generated, at a cost, from an unchanged stock of physical capital. The degree of capital utilization - that is, the difference between the physical capital stock (denoted by an overbar) and capital services - is chosen by households to equate marginal cost and marginal benefit:

$$
E_{t-1}\left[\frac{1}{\sigma_{a}} \widehat{r}_{t}^{k}-\widehat{k}_{t}+\hat{\bar{k}}_{t}\right]
$$

The equilibrium condition for household investment choices can be written as

$$
\widehat{P}_{k^{\prime}, t}=s E_{t-1}\left\{\widehat{i}_{t}-\widehat{i}_{t-1}-\beta\left[\widehat{i}_{t+1}-\widehat{i}_{t}\right]\right\}
$$

This condition indicates that the price firms pay for capital services is a function of two parameters that emerge from the behavior of households: the households' discount factor, $\beta$, and the elasticity of their investment adjustment cost function, $1 / \mathrm{s}$.

The stock of physical capital obeys the law of motion:

$$
\widehat{\bar{k}}_{t+1}=(1-\delta) \widehat{\bar{k}}_{t}+\delta \widehat{i}_{t}
$$

Though physical investment is subject to adjustment costs, this equation indicates that a unit of investment adds to the physical capital stock in a standard manner.

Households' money demand function is given by

$$
\widehat{q}_{t}=-\frac{1}{\sigma_{q}}\left[\frac{R}{R-1} \widehat{R}_{t}+\widehat{\psi}_{t}\right]
$$


a condition that indicates the standard choice between holding money for the transaction services it provides or, instead, holding one-period securities for interest income.

The following identity relates growth of nominal money supply to inflation and changes in real money supply:

$$
\widehat{\mu}_{t-1}+\widehat{m}_{t-1}-\widehat{\pi}_{t}-\widehat{m}_{t}=0
$$

The (linarization of the) loan market clearing condition is:

$$
\mu m\left(\widehat{\mu}_{t}+\widehat{m}_{t}\right)-q \widehat{\bar{q}}_{t}-w L\left(\widehat{w}_{t}+\widehat{L}_{t}\right)=0
$$

The resource constraint and the aggregate production function can be written as

$$
\begin{gathered}
\left(\frac{1}{\beta}+\delta-1\right) \frac{K_{y}}{C_{Y}} u+\widehat{c}_{t}+\delta\left(\frac{K_{y}}{C_{Y}}\right) \widehat{i}_{t}=\left(\frac{\alpha}{C_{Y}}\right) \widehat{k}_{t}+\left(\frac{(1-\alpha)}{C_{Y}}\right) \widehat{L}_{t} \\
\widehat{y}=\alpha \widehat{k}_{t-1}+(1-\alpha) \widehat{L}_{t} \quad(B 16)
\end{gathered}
$$

Equation (B15) indicates that resources this period can be consumed, invested, or used to generate additional capital utilization. Equation (B16) indicates that the two inputs in production are labor and capital services.

Monetary policy follows a Taylor rule:

$$
\widehat{R}_{t}=\rho \widehat{R}_{t-1}+(1-\rho)\left(a_{\pi} E_{t-1} \widehat{\pi}_{t+1}+a_{y} \widehat{y}_{t}\right)+\varepsilon_{t}
$$


Table 4 Variables and parameter definitions

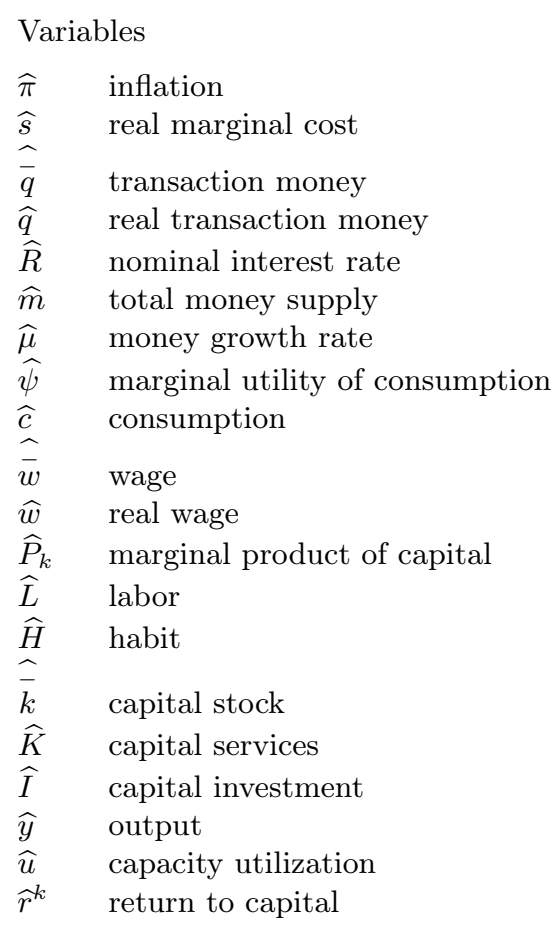

\section{Parameters}

$R \quad$ steady state nominal interest rate

$\beta \quad$ discount rate

$\alpha \quad$ labor share of production

$\delta \quad$ capital depreciation rate

$b_{w} \quad$ simplifying parameter

$\xi_{p} \quad$ price stickiness

$\xi_{w} \quad$ wage stickiness

$\lambda_{w} \quad$ household labor market power

$\bar{\mu} \quad$ steady state money growth rate

$\bar{m} \quad$ steady state $\mathrm{m} 2$

$\bar{q} \quad$ steady state $\mathrm{m} 1$

$\bar{w} \quad$ steady state wage

$\bar{L} \quad$ steady state labor supply

$b$ habit parameter

$\chi \quad$ habit parameter

$\sigma_{c} \quad$ simplifies labor supply decision Euler

$\sigma_{a} \quad$ relates capacity utilization to return on capital

$\sigma_{q} \quad$ relates cash holding and the interest rate

$m c \quad$ steady state marginal cost (1/markup)

$K_{Y} \quad$ steady state capital-output ratio

$C_{Y} \quad$ steady state consumption-output ratio

$\rho \quad$ interest rate smoothing policy parameter

$a_{\pi} \quad$ Taylor rule inflation response

$a_{y} \quad$ Taylor rule output response 


\section{References}

Balke, N. S. And K. M. Emery (1994): "Understanding the price puzzle," Economic and Financial Policy Review, 15-26.

Ball, L., N. G. Mankiw, And D. Romer (1988): "The New Keynsesian Economics and the Output-Inflation Trade-off," Brookings Papers on Economic Activity, 19, 1-82.

Barth, M. J. And V. A. Ramey (2002): "The Cost Channel of Monetary Transmission," in NBER Macroeconomics Annual 2001, Volume 16, National Bureau of Economic Research, Inc, NBER Chapters, 199-256.

Beechey, M. J., B. K. Johannsen, And A. T. Levin (2011): "Are Long-Run Inflation Expectations Anchored More Firmly in the Euro Area Than in the United States?" American Economic Journal: Macroeconomics, 3, 104-29.

Belaygorod, A. And M. Dueker (2009): "Indeterminacy, change points and the price puzzle in an estimated DSGE model," Journal of Economic Dynamics and Control, 33, 624-648.

Benati, L. (2008): "Investigating Inflation Persistence across Monetary Regimes," The Quarterly Journal of Economics, 123, 1005-1060.

Bernanke, B. S., J. Boivin, And P. Eliasz (2005): "Measuring the Effects of Monetary Policy: A FactorAugmented Vector Autoregressive (FAVAR) Approach," The Quarterly Journal of Economics, 120, 387-422.

Blinder, A. S., M. Ehrmann, M. Fratzscher, J. D. HaAn, And D.-J. Jansen (2008): "Central Bank Communication and Monetary Policy: A Survey of Theory and Evidence," Journal of Economic Literature, $46,910-945$.

Boivin, J. And M. P. Giannoni (2006): "Has Monetary Policy Become More Effective?" The Review of Economics and Statistics, 88, 445-462.

Boivin, J., M. P. Giannoni, And I. Minov (2009): "Sticky Prices and Monetary Policy: Evidence from Disaggregated US Data," American Economic Review, 99, 350-84.

Carlstrom, C. T., T. S. Fuerst, and M. Paustian (2009): "Monetary policy shocks, Choleski identification, and DNK models," Journal of Monetary Economics, 56, 1014-1021.

Carvalho, C., S. Eusepi, E. Moench, and B. Preston (2017): "Anchored Inflation Expectations," working paper.

Castelnuovo, E. And P. Surico (2010): "Monetary Policy, Inflation Expectations and The Price Puzzle," Economic Journal, 120, 1262-1283. 
Christiano, L. J., M. Eichenbaum, and C. L. Evans (2005): "Nominal Rigidities and the Dynamic Effects of a Shock to Monetary Policy," Journal of Political Economy, 113, 1-45.

Clarida, R., J. GalÃ, and M. Gertler (2000): "Monetary Policy Rules and Macroeconomic Stability: Evidence and Some Theory," The Quarterly Journal of Economics, 115, 147-180.

DiCecio, R. And E. Nelson (2007): "An estimated DSGE model for the United Kingdom," Working Papers 2007-006, Federal Reserve Bank of St. Louis.

Fernandez-Villaverde, J. and J. F. Rubio-Ramirez (2007): "How Structural Are Structural Parameters?" Working Paper 13166, National Bureau of Economic Research.

Giordani, P. (2004): "An alternative explanation of the price puzzle," Journal of Monetary Economics, 51, $1271-1296$.

Gurkaynak, R., A. Levin, And E. Swanson (2010): "Does Inflation Targeting Anchor Long-Run Inflation Expectations? Evidence from the U.S., UK, and Sweden," Journal of the European Economic Association, 8, $1208-1242$.

Hanson, M. (2004): "The "price puzzle" reconsidered," Journal of Monetary Economics, 51, 1385-1413.

Hofmann, B., G. Peersman, and R. Straub (2012): "Time variation in U.S. wage dynamics," Journal of Monetary Economics, 59, 769-783.

LEePER, E. (1991): "Equilibria under 'active' and 'passive' monetary and fiscal policies," Journal of Monetary Economics, 27, 129-147.

Leeper, E. AND C. Leith (2016): "Understanding Inflation as a Joint Monetary-Fiscal Phenomenon," in Handbook of Macroeconomics, Volume 2, ed. by J. B. Taylor and H. Uhlig, Elsevier, chap. 30, 2305-2415.

Levin, A. T., F. M. Natalucci, And J. M. Piger (2004): "The macroeconomic effects of inflation targeting," Review, 51-80.

LucAs, R. (1976): "Econometric policy evaluation: A critique," Carnegie-Rochester Conference Series on Public Policy, 1, 19-46.

Milcheva, S. (2013): "A bank lending channel or a credit supply shock?" Journal of Macroeconomics, 37, $314-332$.

Potter, S. And J. Rosenberg (2017): "Are US inflation expectations anchored, contained or unmoored?" working paper.

Rabanal, P. (2007): "Does inflation increase after a monetary policy tightening? Answers based on an estimated DSGE model," Journal of Economic Dynamics and Control, 31, 906 - 937. 
Romer, C. D. And D. H. Romer (1994): "Monetary policy matters," Journal of Monetary Economics, 34, $75-88$.

Sims, C. (1992): "Interpreting the macroeconomic time series facts: The effects of monetary policy," European Economic Review, 36, 975-1000.

Smets, F. And R. Wouters (2003): "An Estimated Dynamic Stochastic General Equilibrium Model of the Euro Area," Journal of the European Economic Association, 1, 1123-1175.

Steven, G. (1999): "Six Years of Inflation Targeting," Address to the Economic Society of Australia, Sidney 20 April.

Stock, J. H. And M. W. Watson (1999): "Forecasting inflation," Journal of Monetary Economics, 44, 293-335.

Thapar, A. (2008): "Using private forecasts to estimate the effects of monetary policy," Journal of Monetary Economics, 55, 806-824.

Warne, A., G. Coenen, And K. Christoffel (2008): "The new area-wide model of the euro area: a microfounded open-economy model for forecasting and policy analysis," Working Paper Series 944, European Central Bank. 